\author{
J-ABDIPAMAS (Jurnal Pengabdian Kepada Masyarakat) \\ Vol. $4 \bullet$ No. $2 \bullet 2020$ \\ ISSN : 2581-1320 (Print) ISSN : 2581-2572 (Online) \\ Homepage: http://ejurnal.ikippgribojonegoro.ac.id/index.php/J-ABDIPAMAS
}

\title{
PENDAMPINGAN PELATIHAN PERAWATAN JENAZAH SESUAI DENGAN SYARIAT ISLAM
}

\author{
Sukiyanto ${ }^{1}$, Rofiatun Nisa' ${ }^{2}$, Tsalitsatul Maulidah ${ }^{3}$, Eli Mufidah $^{4}$ \\ ${ }^{1}$ STIT Al-Fattah Siman Lamongan. Email: sukiyanto@stitaf.ac.id \\ ${ }^{2}$ STIT Al-Fattah Siman Lamongan. Email: rofiatunnisa @stitaf.ac.id \\ 3Universitas Billfath. Email: tsalisatulmaulidah@billfathac.id \\ ${ }^{4}$ STIT Al-Fattah Siman Lamongan. Email: elimufidah@stitaf.ac.id
}

\begin{abstract}
Every living creatures, including humans, will inevitably experience death. Because taking care of the corpse is a form of caring and respect for fellow Muslims. So we as a Muslims must know the procedures and rules for treating corpse. Thus that this corpse care training can contribute to helping the community to add officers who can organize the corpse so that the difficulty in finding the corpse organizers is overcome and trying to improve the ability of Bluluk villagers, about rules for treating corpse according to Islamic law. There are three steps used in the training for treating corpse, namely lecture method, FGD (Focus Group Discussion), and practice of genizah management. The results obtained from this training were the Muslim NU group, and the surrounding community gained an understanding and mastered the concept of managing corpses and mastering the basics of managing Muslim corpses so that they could apply them in practice by the Al-Qur'an and the Sunnah and pay attention to manners in each the process. And the Muslim NU group and the surrounding community were willing to form a corpse management team so that they could contribute to the community.
\end{abstract}

Keywords: Training, corpse care. Islamic Law.

\begin{abstract}
ABSTRAK
Setiap makhluk hidup, termasuk juga manusia pasti akan mengalami mati. Karena mengurus jenazah merupakan salah satu bentuk kepedulian dan penghormatan kepada sesama muslim. Jadi kita sebagai seorang muslim harus mengetahui tata cara dan aturan dalam perawatan jenazah. Sehingga pelatihan perawatan jenazah ini dapat memberikan kontribusi untuk membantu masyarakat untuk menambah petugas yang dapat menyelenggarakan jenazah sehingga kesulitan dalam mencari tenaga penyelenggara jenazah teratasi dan berupaya meningkatkan kemampuan warga masyarakat desa Bluluk, mengenai aturan dalam perawatan jenazah menurut syariat Islam. Terdapat tiga langkah yang digunakan dalam pelatihan perawatan jenazah ini yaitu metode ceramah, FGD (Focus Group Discussion), dan praktik pengurusan jeanzah. Hasil yang didapat dari pelatihan ini yaitu kelompok muslimat NU dan masyarakat sekitar mendapatkan pemahaman dan menguasai konsep mengenai pengurusan jenazah dan menguasai dasardasar pengurusan jenazah muslim, sehingga dapat mengaplikasikannya dengan praktik yang sesuai dengan Al-Quran dan Sunnah serta memperhatikan adab-adab dalam setiap prosesnya. Dan kelompok muslimat NU dan masyarakat sekitar bersedia membentuk tim pengurusan jenazah sehingga dapat berkontribusi terhadap masyarakat.
\end{abstract}

Kata Kunci: Pelatihan, Perawatan jenazah. Syariat Islam. 


\section{PENDAHULUAN}

Perawatan terhadap jenazah merupakan suatu runtutan tata cara yang bertujuan untuk memuliakan jasad manusia yang telah meninggal. Sebagai bentuk penghormatan terakhir terhadap sesama makhluk ciptaan Allah. Merawat jenazah juga merupakan salah satu tuntunan syariat Islam yang telah diajarkan oleh Rasulullah SAW, namun dalam kenyataannya sebagian besar masyarakat melakukannya berdasarkan kebiasaan saja, atau dengan cara melihat para pendahulunya tanpa mengerti dalil dan petunjuk secara benar. Padahal kita mengetahui di antara masalah penting yang terkait dengan hubungan manusia dengan manusia lainnya adalah masalah perawatan jenazah. Oleh karena itu agama Islam menaruh perhatian yang sangat serius dalam masalah ini, sehingga hal ini termasuk salah satu kewajiban yang harus dipenuhi oleh umat manusia, khususnya umat Islam (Abdul, 2006).

Mengurus jenazah, merupakan salah satu bentuk kepedulian dan penghormatan kepada sesama muslim. Diantaranya kewajiban-kewajiban yang dilakukan yaitu yaitu sejak dari menyiapkan, memandikan, mengkafani, menshalatkan, dan membawanya ke kubur sampai kepada menguburkannya adalah perintah agama yang ditujukan kepada kaum muslimin sebagai kelompok masyarakat (Maimunah, 2019). Apabila perintah itu telah dikerjakan oleh sebahagian mereka sebagaimana mestinya, maka kewajiban melaksanakan perintah itu berarti sudah terbayar. Kewajiban yang demikian sifatnya dalam istilah agama dinamakan fardhu kifayah. Karena semua amal ibadah harus dikerjakan dengan ilmu, maka mempelajari ilmu tentang peraturan-peraturan di sekitar penyelengaraan jenazah itupun merupakan fardhu kifayah juga. Walaupun penyelenggaraan jenazah itu merupakan fardhu kifayah, tetapi agama menganjurkan supaya sebanyak mungkin orang menyertai shalat jenazah, mengantarnya ke kubur dan menyaksikan penguburannya. Selain itu Islam menjadikan perihal pengurusan jenazah berkaitan erat dengan pemenuhan hak muslim terhadap muslim lainnya (Istianah \& Safitri, 2019).

Oleh sebab itu, kalau seseorang tidak menguasai ilmu tentang aturan agamanya mengenai perkara ini, akan sangat aib baginya. Hal tersebut terjadi di desa Bluluk kecamatan Bluluk, yang masyarakatnya mayoritas beragama Islam, penyelenggaraan jenazah menurut aturan agama Islam merupakan suatu kewajiban. Fenomena yang terjadi didesa tersebut, terjadi suatu kekurangan sumber daya masyarakat (SDM) yang mengetahui tentang keterampilan dalam perawatan jenazah, faktor penyebab lainnya yaitu minimnya tempat untuk belajar tentang perawatan jenazah sehingga hal ini mengakibatkan kurangnya minat masyarakat untuk mempelajari tatacara perawatan jenazah. Dengan demikian, sangat diperlukan suatu pelatihan perawatan jenazah yang sesuai dengan syariat Islam.

Pelatihan merupakan suatu upaya untuk mengembangkan sumber daya manusia, terutama untuk mengembangkan kemampuan intelektual, ketrampilan dan kepribadian manusia (Mega, dkk: 2016). Pelatihan merupakan salah satu upaya untuk meningkatkan kualitas diri pada sumber daya manusia (Muhlis, dkk: 2018). Sedangkan menurut Fernando (2013) mendefinisikan pelatihan merupakan suatu proses belajar mengajar 
dengan menggunakan teknik dan metode tertentu secara konsepsional dan dapat dikatakan bahwa latihan dimaksudkan untuk meningkatkan ketrampilan dan kemampuan seseorang atau sekelompok orang.

Dari beberapa pendapat diatas maka dapat disimpulkan bahwa pelatihan merupakan suatu proses yang bertujuan meningkatkan kemampuan sumber daya manusia. Kemampuan dimaksud adalah pengetahuan, ketrampilan, dan kepribadian. Pelatihan sebagai proses pembelajaran yang bertujuan untuk meningkatkan kemampuan seseorang sebagai akibat keterbatasan kemampuan kerja yang dimilikinya. Berdasarkan hal tersebut, pelatihan perawatan jenazah ini dapat memberikan kontribusi untuk membantu masyarakat untuk menambah petugas yang dapat menyelenggarakan jenazah sehingga kesulitan dalam mencari tenaga penyelenggara jenazah teratasi dan berupaya meningkatkan kemampuan warga masyarakat desa Bluluk, dalam hal menyelenggarakan jenazah menurut syariat Islam.

\section{METODE PELAKSANAAN}

Pengabdian ini menggunakan metode pelatihan untuk mengembangkan kecakapan baik teori dan praktik manajemen pengurusan jenazah. Pelatihan ini dilaksanakan di Masjid Al-Mujahiddin desa Bluluk kecamatan Bluluk. Peserta pelatihan ini dari tokohtokoh desa Bluluk, kelompok muslimat NU kecamatan Bluluk dan masyarakat sekitar yang dihadiri oleh 85 peserta. Alat-alat yang dibutuhkan dalam hal ini yaitu buku panduan Tajhizul Mayyit untuk peserta, dan difokuskan kepada kebutuhan praktik mengkafani jenazah, yaitu berupa berupa: kain kafan sekitar 12 meter yang dipotong menjadi 3 helai sepanjang $2 \times 1$ meter, tali pengikat $3 \times 100 \mathrm{~cm}$ sebanyak 7 helai, kerudung, baju kurung, dan kain basahan; kapas; kapur barus yang dihaluskan; sisir; dan meja untuk membentangkan kain kafan. Pelatihan ini dilaksanakan dengan langkahlangkah sebagai berikut:

1. Metode ceramah, yaitu untuk menyampaikan teori seputar kematian, adab dan proses serta tata cara pengurusan jenazah muslim. Pada tahap ini dibagi ke dalam dua sesi, sesi pertama yaitu teori seputar makna kematian, serta cara pendampingan terhadap orang menghadapi sakaratul maut, dan adab-adab menjelang pengurusan jenazah, serta hikmah dan keutamaan pengurusan jenazah. Materi ini disampaikan oleh KH. Muntahal Khoir dari Pondok Pesantren Langitan Widang Tuban. Sedangkan sesi kedua, yaitu teori seputar hukum dan tata cara pengurusan jenazah muslim, kemudian dilanjutkan dengan praktik memandikan, mengkafani, dan menshalati jenazah muslim.

2. Metode FGD (Focus Group Discussion) dan dialog, pada tahap ini tim mengajak peserta melakukan sharing mengenai pengurusan jenazah yang umumnya terjadi di lingkungan desa Bluluk.

3. Metode praktik, yaitu praktik tata cara pengurusan jenazah untuk menanamkan keterampilan teknis dan praktis terkait hal tersebut berupa praktik memandikan, mengkafani, dan menshalati jenazah muslim. Pada sesi praktik ini peserta dibagi ke dalam empat kelompok, di mana masing-masing kelompok mempraktikkan tahapantahapan pengurusan jenazah. 


\section{HASIL DAN PEMBAHASAN}

Sebagian besar anggota kelompok muslimat NU dan masyarakat sekitar, selama ini belum memperhatikan proses pengurusan jenazah muslim yang berada di desa Bluluk secara serius. Padahal kebutuhan masyarakat akan hal tersebut cukup tinggi dan belum ada organisasi atau swadaya masyarakat yang menyediakan jasa pengurusan jenazah, hanya saja biasanya dilakukan oleh modin desa dan keluarga yang ditinggalkan. Namun, sebagian besar dari 85 peserta yang mengikuti pelatihan belum pernah mendapatkan pelatihan pengurusan jenazah secara menyeluruh dimulai dari pemahaman akan kematian, adab-adab terhadap orang yang menghadapi sakaratul maut, adab terhadap jenazah dan tata cara pengurusannya.

Pelatihan ini berjalan dengan baik dan mendapatkan sambutan yang sangat antusias dari peserta. Peserta pun mendapatkan pelatihan secara lengkap baik berupa teori maupun praktik. Pada sesi pertama dilakukan pembukaan, yaitu berdoa dengan doa pembukaan dan sharing pengalaman dalam hal pengurusan jenazah dan budaya masyarakat dalam hal tersebut.

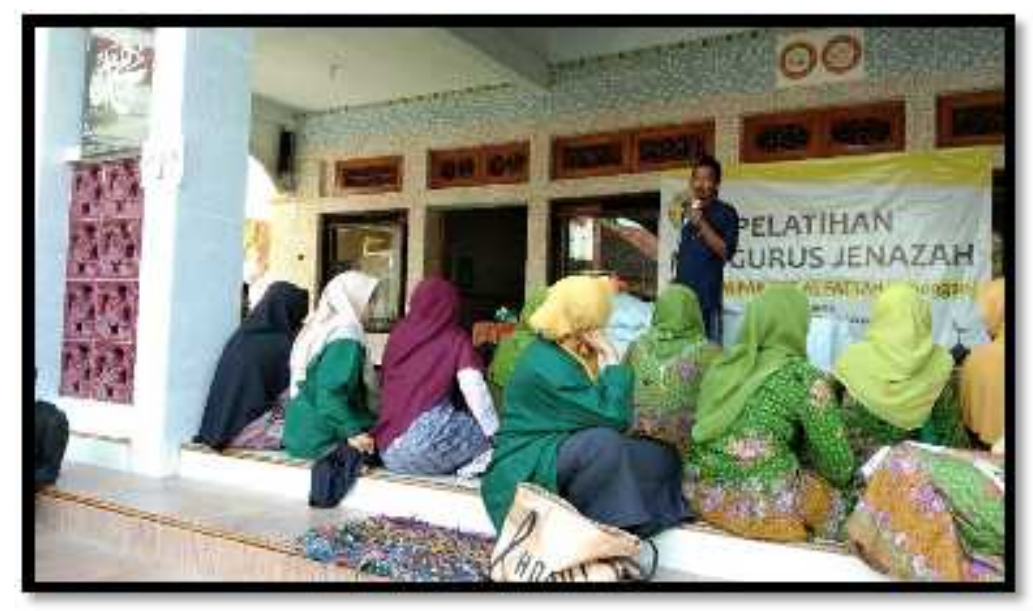

Gambar 1. Tahap metode ceramah

Hasil dari FGD (Focus Group Discussion) tersebut ditemukan bahwa sebagian peserta masih fobia terhadap jenazah, demikian juga masyarakat sekitar masih sering kali tidak memperhatikan adab-adab terhadap jenazah. Dalam hal ini, kelompok muslimat NU dapat mengambil andil mulai dari kegiatan edukasi masyarakat dalam hal pemahaman tentang pengurusan jenazah yang baik sesuai syariat Islam sampai dengan memberikan pelayanan pengurusan jenazah. Pelayanan yang dimaksud sebenarnya merupakan salah satu aktivitas dakwah yang memerlukan manajemen yang baik, bukan sesuatu yang dilaksanakan sambil lalu atau bahkan asal-asalan, melainkan harus melalui proses persiapan dan perencanaan yang matang (Sholeh, 2010).

Pada sesi berikutnya, memberikan materi dengan menyampaikan materi perawatan jenazah dimulai dari materi yang sesuai dengan tuntunan Rasulullah, teori tentang makna kematian, orang yang menghadapi kematian, serta menjelang pengurusan jenazah. Termasuk dalam materi ini adalah keutamaan dan hikmat pengurusan jenazah yang dimaksudkan akan menumbuhkan motivasi peserta dalam hal ini. Teori berikutnya yaitu tentang manajemen pengurusan jenazah mulai dari 
memandikan, mengkafani, dan menshalati. Dan selanjutnya menyiapkan dan meletakkan bahan dan alat-alat yang akan dipakai ketika praktek perawatan jenazah Kemudian pada sesi terakhir, peserta dibentuk dalam beberapa kelompok untuk mempraktikkan proses pengurusan jenazah. Sehingga dapat disimpulkan bahwa pengetahuan peserta tentang proses pengurusan jenazah telah meningkat jika dibandingkan dengan keadaan pra pelatihan dan proses transfer ilmu telah mencapai

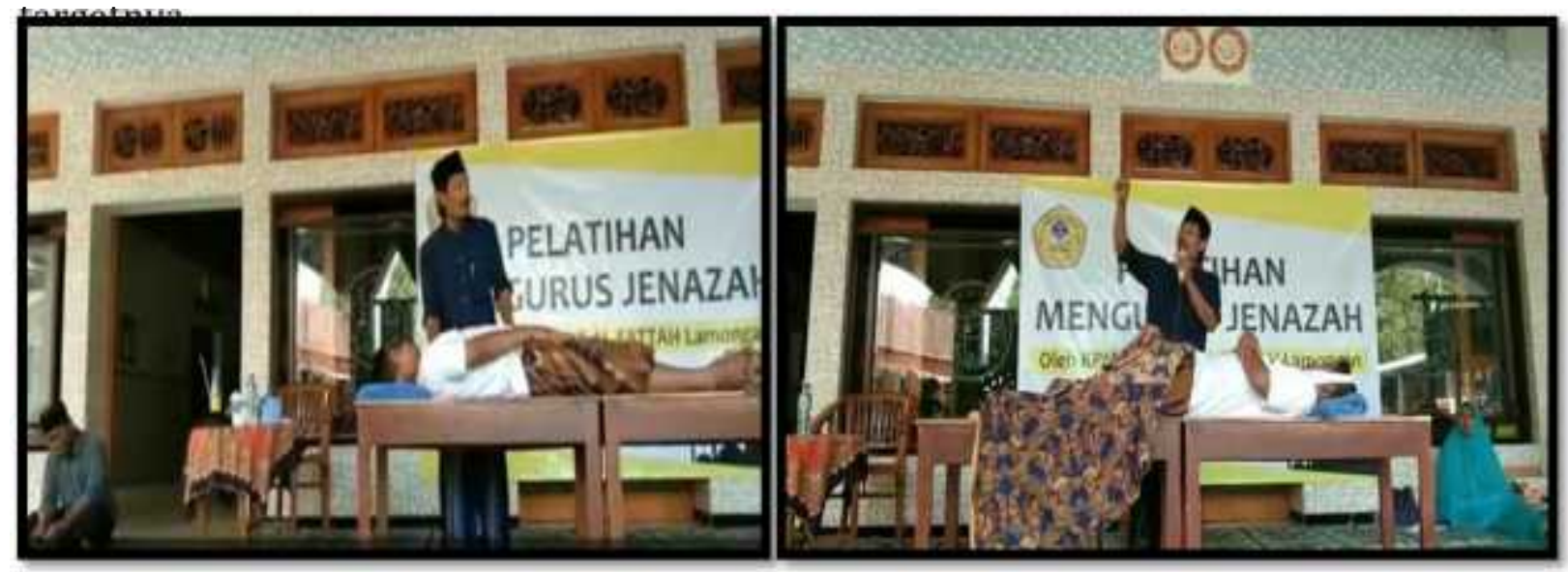

Gambar 2. Proses perawatan Jenazah

Peserta pelatihan sangat bersemangat dan antusias untuk mewujudkan terbentuknya tim pengurusan jenazah di desa Bluluk. Karena selama ini pengurusan jenazah di desa Bluluk, dilakukan oleh modin desa jika jenazah laki-laki dan istri moden jika jenazah perempuan, dan dibantu oleh keluarga jenazah. Untuk mengatisipasi saat purnanya modin desa, maka peserta sangat semangat untuk mempelajari perawatan jenazah. Adapun luaran kegiatan pengabdian ini berupa: 1) pemahaman mitra mengenai pengurusan jenazah; 2) peningkatan jumlah SDM yang menguasai konsep dasar pengurusan jenazah; 3) persiapan dan kesediaan mitra dalam hal pengurusan jenazah sebagai bentuk kepedulian terhadap masyarakat sekitar.

Pada pelaksanaan kegiatan pengabdian ini terdapat faktor penghambat dan faktor pendukung. Faktor-faktor penghambat yang dimaksud di antaranya: 1) Terbatasnya tenaga ahli dalam pelaksanaan pelatihan perawatan jenazah; 2) Sulitnya menentukan waktu pelaksanaan pelatihan perawatan jenazah antara tenaga ahli dengan masyarakat, sehingga membuat pelaksanaan kegiatan harus bergeser mundur beberapa kali.. Sedangkan faktor pendukung yang dimaksudkan di antaranya: 1) semangat peserta untuk meningkatkan wawasan mengenai pengurusan jenazah menjadi modal utama dalam pelaksanaan pengabdian ini. Pelatihan pengurusan jenazah pun masih merupakan hal yang baru bagi sebagian besar anggota mitra; 2) peserta menghadapi kebutuhan mendesak berupa pemahaman tentang konsep pengurusan jenazah muslim yang sesuai dengan al-Quran dan sunnah untuk segera diaplikasikan di masyarakat sekitar, di mana mayoritas warganya kerap mengabaikan adab dan etika pengurusan jenazah; 3) kesigapan kelompok muslimat NU serta masyarakat sekitar dalam koordinasi dan teknis persiapan kegiatan sehingga membantu kelancaran pelaksanaan kegiatan. 


\section{SIMPULAN}

Kesimpulan yang didapat dari pelatihan ini yaitu 1) anggota kelompok muslimat NU dan masyarakat sekitar mendapatkan pemahaman mengenai pengurusan jenazah dan menguasai dasar-dasar pengurusan jenazah muslim; 2) anggota kelompok muslimat NU dan masyarakat sekitar menguasai konsep pengurusan jenazah sehingga dapat mengaplikasikannya dengan praktik yang sesuai dengan Al-Quran dan Sunnah serta memperhatikan adab-adab dalam setiap prosesnya; 3) anggota kelompok muslimat NU dan masyarakat sekitar bersedia membentuk tim pengurusan jenazah sehingga dapat berkontribusi terhadap masyarakat.

\section{DAFTAR RUJUKAN}

Abdul, Karim. (2006). Petunjuk Perawatan Jenazah dan Sholat Jenazah, cet IV. Jakarta:Azmah.

Fernando, S.L. (2013). Pengaruh Pelatihan Pemberdayaan dan Efikasi Diri Terhadap Kepuasan Kerja. Jurnal Emba. 1(3). Hal: 747-755

Istianah \& Safitri, M. (2019). Pemberdayaan Keagamaan PDNA Banyumas Melalui Manajemen Perawatan Jenazah. Seminar Nasional Hasil Penelitian dan Pengabdian Pada Masyarakat IV. LPPM: Universitas Muhammadiyah Purwokerto.

Maimunah, S. (2019). Bimbingan Perawatan Jenazah dengan Penyakit HIV/AIDS Bagi Santri Pondok Pesantren Lubbul Labib Kedungsari Maron Probolinggo. Jurnal Ilmiah Keperawatan (Scientific Journal of Nursing), 5(2), hal: 121-125.

Mega, L. Azis, F. Maria, M.M. (2016). Studi Deskriptif Pelatihan dan Pengembangan Sumberdaya Manusia Serta Penggunaan Metode Behavioral Event Interview dalam Merekrut Karyawan Baru di Bank Mega Cabang Kudus. Journal of Management. 2(2).

Muhlis, M. Soepeno. Rachmatulaily, T.K.R. (2018). Pelatihan dan Pemotivasian Terhadap Pengembangan Karir Karyawan. Jurnal Ilmu Manajemen. 1(1).

Sholeh, Rosyad. (2010). Manajemen Dakwah Islam. Yogyakarta: Suara Muhammadiyah. 